\title{
SENTRALISASI MANAGEMEN KEUANGAN SEBAGAI UPAYA MENINGKATKAN MUTU PENDIDIKAN DI YAYASAN AL MAHRUSIYAH LIRBOYO KEDIRI
}

\author{
Muchlis \\ Program Pascasarjana Institute Agama Islam Tribakti Kediri
}

\begin{abstract}
Abstrak
Penggunaan metode pembelajaran yang tepat untuk meningkatkan mutu pembelajran harus terus ditingkPenelitian ini dibingkai dalam topik besar Managemen Keuangan yang secara khusus melihat langsung praktek keuangan di Yayasan Al Mahrusiyah Lirboyo Kediri dari praktek keuangan yang ada di kantor pusat administrasi yang kemudian berkembang ke beberapa Lembaga Pendidikan di bawah naungan Yayasan Al Mahrusiyah dengan kualitas atau mutu pendidikan di lembaga pendidikan dalam naungan Yayasan Al Mahrusiyah Lirboyo Kediri.

Permasalahan yang diajukan dalam penelitian ini meliputi pertanyaan, 1) bagaimanakah Managemen keuangan yang ada di Yayasan Al Mahrusiyah dan Lembaga Pendidikan dalam naungannya, 2) bagaimana mutu pendidikan dalam lembaga pendidikan yang ada di bawah naungan Yayasan Al Mahrusiyah Lirboyo Kediri.

Jenis pendekatan penelitian ini adalah kualitatif. Sebagaimana arahan jenis penelitian kualitatif, maka data terkumpul dianalisis dengan bekal senjata intelektual berupa teori sebagaimana ditampilkan dalam Bab II untuk mendapatkan berbagai uraian interpretatif sesuai kaidah penelitian ilmiah yang logis dan rasional atas data yang dikumpulkan. Untuk metode penulis menggunakan metode Deskriptif yang pada hakikatnya adalah mencari teori, bukan menguji teori. Metode ini menitikberatkan pada observasi dan suasana alamiah.

Akhirnya, penelitian ini berhasil memperoleh temuan sesuai pertanyaan permasalahan yang pada garis besarnya dapat disimpulkan sebagai berikut. 1) Managemen keuangan yang ada di Yayasan Al Mahrusiyah Lirboyo Kediri sudah menunjukkan Managemen yang standar bahkan sentralisasi keuangan merupakan sistem managemen yang sudah berjalan dengan baik, sehingga ada beberapa Yayasan yang mengadakan studi banding di Yayasan ini. 2) kualitas pendidikan yang ada dibawah naungan Yayasan Al Mahrusiyah Lirboyo Kediri menunjukkan kualitas pendidikan yang dapat bersaing dengan kualitas pendidikan di lembaga pendidikan negeri dengan bukti banyak lulusanya yang di terima sekolah-sekolah ataupun universitas-universitas negeri, maka dapat disimpulkan bahwa dengan Managemen keuangan yang baik yakni sentralisasi keuangan menjadi salah satu penyebab naiknya kualitas pendidikan di lembaga pendidikan di bawah naungan Yayasan Al Mahrusiyah Lirboyo Kediri. Saran penulis bahwa Yayasan yang mengutamakan Managemen khususnya managemen sentralisasi baik keuangan maupun pendidikan adalah Yayasan yang patut di jadikan uswatun hasanah. Sebab sesuatu yang buruk jika diatur atau dimanag terkadang mengalahkan sesuatu yang baik tanpa diatur atau di manag.
\end{abstract}

Kata Kunci: Managemen Keuangan, Mutu Pendidikan

\section{Konteks Penelitian}

Lembaga pendidikan Islam sebagaimana lembaga pendidikan pada umumnya memiliki tanggung jawab besar dalam mewujudkan citacita luhur mencerdaskan kehidupan bangsa dan membentuk kepribadian bangsa yang berbudi luhur serta mempersiapkan sumber daya manusia yang berkualitas sehingga mampu berkompetisi dalam persaingan dunia global. Dengan demikian satu kata kunci untuk mencapai itu semua adalah peningkatan mutu pendidikan tidak bisa ditunda-tunda 
lagi. Peningkatan kualitas pendidikan bukanlah tugas ringan karena tidak hanya berkaitan dengan permasalahan teknis, tetapi mencakup berbagai persoalan yang sangat rumit dan kompleks, baik yang menyangkut perencanaan, pendanaan, maupun efisiensi dan efektifitas penyelenggaraan sistem sekolah. Dalam konteks satuan pendidikan, mekanisme penetapan besaran BOS berdasarkan variabel jumlah siswa kurang tepat. Sekolah yang siswanya lebih banyak menerima dana banyak, sedangkan sekolah yang siswanya sedikit memperoleh dana sedikit. Padahal, pembiayaan satuan pendidikan lebih banyak dipengaruhi oleh basis rombongan belajar. Artinya, dalam satu rombongan belajar biaya operasionalnya relatif sama, baik dengan jumlah murid banyak maupun sedikit.

Mengingat pentingnya keuangan dalam menjalankan roda lembaga pendiddikan di bawah nauangan Yayasan Al Mahrusiyah Lirboyo Kediri, penulis tertarik untuk meneliti sejauh mana managemen keuangan yang ada di Yayasan sampai bisa membawa Yayasan berikut lembaga-lembaga yang ada di bawahnya mengalami peningkatan yang signifikan dalam bidang pendidikan dan sarana prasarana berikut autput yang dihasilkannya.

Oleh karena dalam tulisan ini akan mengupas dilema di atas dengan melaksanakan teori sentralisasi managemen keuangan di Yayasan Al Mahrusiyah Lirboyo Kediri, yang tentunya sangat menarik sekali dan penasaran atas keberhasilan sistem ini. Semoga bermanfaat khususnya pihak Yayasan sendiri umumnya para pembaca yang budiman.

\section{A. Fokus Penelitian}

Berkenaan dengan hal tersebut, demi terwujudnya pembahasan yang terarah dan sesuai dengan rencana yang diharapkan maka penulis rumuskan beberapa masalah sebagai berikut:

1. Bagaimana managemen keuangan di Yayasan Al Mahrusiyah Lirboyo Kediri ?

2. Bagaimana kualitas pendidikan dalam naungan Yayasan Al mahrusiyah Lirboyo Kediri ?

\section{Kajian Teori \\ Managemen Keuangan}

Secara etimologi, kata managemen berasal dari bahasa Perancis Kuno menagement, yang memiliki arti seni melaksanakan dan mengatur. Dalam bahasa Inggris, kata manajemen berasal dari kata to manage artinya mengelola, membimbing dan mengawasi. Jika diambil dalam bahasa Italia, berasal dari kata maneggiare memiliki arti mengendalikan, terutamanya mengendalikan kuda. Sementara itu dalam bahasa Latin, kata manajemen berasal dari kata manus yang berarti tangan dan agere yang berarti melakukan, jika digabung memiliki arti menangani.

Secara terminologi, para ahli tidak memiliki rumusan yang sama tentang definisi manajemen. Stoner sebagaimana dikutip Handoko merumuskan manajemen sebagai proses perencanaan, pengorganisasian, pengarahan, dan pengawasan usaha-usaha para anggota organisasi dan penggunaan sumbersumber daya organisasi lainnya agar mencapai tujuan organisasi yang telah ditetapkan.

Pengertian manajemen keuangan dalam arti sempit adalah tata pembukuan. Sedangkan dalam arti luas adalah pengurusan dan pertanggung jawaban dalam menggunakan keuangan baik pemerintah pusat maupun daerah. Adapun Maisyarah menjelaskan bahwa manajemen keuangan adalah suatu proses melakukan kegiatan mengatur keuangan dengan menggerakkan tenaga orang lain. Kegiatan ini dapat dimulai dari perencanaan, pengorganisasian, pelaksanaan sampai dengan pengawasan. Dalam manajemen keuangan di sekolah tersebut dimulai dengan perencanaan anggaran sampai dengan pengawasan dan pertanggung jawaban keuangan.

\section{Kualitas atau Mutu Pendidikan}

Mutu memiliki konotasi yang bermacammacam tergantung orang yang memakainya. Kata mutu diambil dari bahasa latin "Qualis" yang artinya what kind of (tergantung dengan kata apa yang mengikutinya). Pengertian mutu sendiri menurut Deming ialah kesesuaian 
dengan kebutuhan. Sedangkan menurut Juran, mutu ialah kecocokan dengan kebutuhan. Sallis (2003) mengemukakan bahwa mutu adalah konsep yang absolut dan relatif. Mutu yang absolut adalah mutu yang mempunyai idealisme tinggi dan berstandar tinggi yang harus dipenuhi, dengan sifat produk bergengsi yang tinggi. Sedangkan mutu relatif adalah sebuah alat yang sudah ditetapkan dan harus memenuhi standar yang telah dibuat.

Mutu proses pembelajaran mengandung makna bahwa kemampuan sumber daya sekolah mentransformasikan multi jenis masukan dan situasi untuk mencapai derajat nilai tambah tertentu dari peserta didik. Dilihat dari hasil pendidikan, mutu pendidikan dipandang berkualitas jika mampu melahirkan keunggulan akademis dan ekstrakurikuler pada peserta didik yang dinyatakan lulus untuk satu jenjang pendidikan atau menyelesaikan program pembelajaran tertentu.

Dengan demikian kualitas jasa pendidikan dapat diketahui dengan cara membandingkan persepsi pelanggan atas pelayanan yang diperoleh atau diterima secara nyata oleh mereka dengan dengan pelayanan yang sesungguhnya diharapkan. Jika kenyataan lebih dari yang diharapkan, pelayanan dapat dikatakan bermutu. Sebaliknya, jika kenyataan kurang dari yang diharapkan, pelayanan dapat dikatakan tidak bermutu. Namun, apabila kenyataan sama dengan harapan, maka kualitas pelayanan disebut memuaskan. Dengan demikian, kualitas pelayanan dapat didefinisikan seberapa jauh perbedaan antara kenyataan dan harapan para pelanggan atas layanan yang diterima mereka.

Dalam UU Sisdiknas Pasal 1 ayat 1 dikatakan bahwa Pendidikan adalah usaha sadar untuk mewujudkan suasana belajar dan proses pembelajaran agar peserta didik secara aktif mengembangkan prtensi dirinya untuk memiliki kekuatan spiritual keagamaan, pengendalian diri, kepribadian, kecerdasan, akhlak mulia, serta keterampilan yang diperlukan dirinya, masyarakat, bangsa dan negara.

Pendidikan adalah usaha sadar dan terencana untuk mewujudkan suasana belajar dan proses pembelajaran agar peserta didik secara aktif mengembangkan potensi dirinya untuk memiliki kekuatan spiritual keagamaan, pengendalian diri, kepribadian, kecerdasan, aklak mulia, serta ketrampilan yang diperlukan dirinya, masyarakat, bangsa dan negara

Menurut M.J. Langeveld, Pendidikan adalah merupakan upaya manusia dewasa membimbing manusia yang belum dewasa kepada kedewasaan. Pendidikan ialah usaha menolong anak untuk melaksanakan tugastugas hidupnya, agar bisa mandiri, akil-baliq, dan bertanggung jawab secara susila. Pendidikan adalah usaha mencapai penentuan-diri-susila dan tanggung jawab.

\section{Managemen Pendidikan}

Sedangkan manajemen pendidikan sendiri mengandung arti suatu ilmu yang mempelajari bagaimana menata sumber daya untuk mencapai tujuan yang telah ditetapkan secara produktif dan bagaimana menciptakan suasana yang baik bagi manusia yang turut serta dalam mencapai tujuan yang disepakati bersama.

Salah satu obyek garapan dalam manajemen pendidikan adalah menajemen keuangan. Kegiatan di sekolah yang sangat kompleks membutuhkan pengaturan keuangan yang baik. Keuangan di sekolah merupakan bagian yang amat penting sebab setiap kegiatan membutuhkan pendanaan (uang). Untuk itu perlu manajemen keuangan yang baik sehingga seluruh program sekolah yang telah disusun dapat terlaksana dengan baik. Manajemen keuangan (financial management) mengandung makna segala aktivitas organisasi yang berhubungan dengan bagaimana memperoleh dana, menggunakan dana, dan mengelola aset sesuai tujuan organisasi secara menyeluruh.

Dilihat dari pengertian manajemen dan pengertian pendidikan diatas, maka kita dapat mendefinisikan Manajemen Pendidikan sebagai suatu Proses perencanaan, pengorganisasian, pelaksanaan dan pengawasan dalam mengelola sumber daya yang berupa man, money, materials, method, machines, market, minute dan information untuk mencapai tujuan yang efektif dan efisien dalam bidang pendidikan. 


\section{Paparan Data}

\section{A. Menejemen Keuangan Yayasan Al Mahrusiyah Lirboyo Kediri}

\section{Menejemen Keuangan sebelum Sentralisasi atau adanya Kantor Pusat Administrasi (KPA).}

Manajemen keuangan yang ada sekarang adalah manajemen keuangan yang sebelumnya masih dalam manajemen keuangan lembagalembaga di bawah naungan Yayasan Tribakti. Pada tahun 1986 cikal bakal madrasah aliyah dan madrasah tsanawiyah merupakan 2 lembaga yang berada di kamus Tribakti ini manajemen keuangannya masih diatur atau dimenej oleh lembaga masing-masing, sehingga mengalami kendala ketika beliau KH Imam Yahya Mahrus sebagai Pengasuhnya membangun gedung sekolahan Tsanawiyah misalnya kekurangan dana atau dana di bendahara Tsanawiyah habis, bingung mencari pinjaman.

Masing-masing lembaga mengurusi administrasinya sendiri-sendiri tanpa adanya kerjasama, padahal masih dalam satu pengasuh. Hal ini memicu persaingan yang kurang sehat di antara kedua lembaga, sampai muncul kecemburuan sosial yang mengarah pada administrasi yang kurang sehat, terutama masalah keuangan yang pada akhirnya terjadi gejolak yang ditandai dengan demo para siswa dan pihak lain dari luar sekolahan yang pro dan kontra terhadap kebijakan kepala sekolah Aliyah Tribakti pada waktu itu. Hal ini penulis anggap suatu kejadian yang ironis sekali jika dikaitkan dengan suatu lembaga yang ada di sebuah pesantren apalagi pesantren agung Lirboyo Kediri.

Suatu Pesantren yang menjunjung tinggi akhlak mulia dalam segala aspek kehidupan, sebagai barometer tegaknya budi pakerti suatu bangsa, karakter mulia sebagai benteng pengaruh negatif globalisasi, perlu adanya suatu perjuangan untuk mempertahankan karakter tersebut.

\section{Manajemen Keuangan setelah Sentralisasi atau adanya Kantor Pusat Administrasi (KPA).}

Nah untuk mengantisipasi kekurangan dana di salah satu lembaga, maka beliau menggabungkan atau menjadikan satu manajemen keuangannya di suatu tempat yang akhirnya dinamakan Kantor Pusat Administrasi (KPA) Yayasan Al Mahrusiyah. Disamping tujuan pendirian Kantor Pusat Administrasi tersebut memudahkan Yayasan untuk operasionalnya, juga memudahkan untuk kontroling keuangan dalam sebuah Yayasan. ${ }^{1}$

Dalam menjalankan operasianalnya Yayasan bisa mudah untuk mengontrol atau mengevaluasi kinerja Yayasan dan Lembagalembaga yang ada di bawahnya melalui suatu lembaga yang menjadi jembatan yang menghubungkan antara Yayasan dan lembaga-lembaga di bawahnya, yang akhirnya terbentuklah Kantor Pusat Administrasi Yayasan Al Mahrusiyah atau disingkat dengan KPA, kantor ini mengurusi semua kegiatan belajar mengajar baik dalam bidang keuangan maupun dalam masalah kegiatan yang lainnya. ${ }^{2}$

Manajemen keuangan yang ada di Yayasan Al Mahrusiyah menganut paham sentralisasi manajemen terutama masalah keuangan. Sedangkan masalah yang lainnya masih belum keseluruhannya dapat di sentralisasi di Kantor Pusat Administrasi (KPA). Di antara masalah yang sudah disentralisasi selain keuangan adalah ketenagakerjaan yang ada, baik masalah pengrekrutan tenaga kerja maupun masalah pemutasian keluar tenega kerja yang tidak mentaati peraturan Yayasan.

Kantor pusat administrasi sudah membuat Identitas siswa atau santri (ID), sehingga setiap santri selama mondok atau sekolah di Yayasan Al Mahrusiyah punya ID, dan tidak akan berubah selamanya. ID tersebut bisa memudahkan pengoperasian siswa dalam masalah apa saja, terutama masalah keuangan. Diantaranya memudahkan wali santri dalam pengiriman uang atau transfer ke anaknya untuk mengklarifikasi kiriman yaitu cukup membubuhkan tiga angka dari ID anak ke nominal uang yang ditransfer tepatnya di tiga angka terakhir dari nominal uang yang

1 Dari M. Irfan Zainul Fuad, salah seorang yang penulis mintai penjelasan alasan didirikan Kantor Pusat Administrasi Yayasan Al Mahrusiyah.

2 Dari penulis sendiri, ketepatan Penulis sebagai bagian keuangan di kantor KPA. 
ditransfer. Misalnya orang tua santri mau kirim satu juta (1.000.000;), sedangkan ID anaknya 14-0123 artinya anak tersebut mulai mondok tahun 2014 dengan nomor urut pendaftaran namor 123, maka cukup menulis 1.000.123; di slip pentrasferan yang ada di bank dimana mereka mentransfernya, kemudian wali santri mengkonfirmasi ke kantor Sentral atau KPA melalui Telp 0354775932 atau HP 085735691010 selanjutnya bukti transferan difaximilkan ke 0354 770301, sehingga memudahkan wali santri dan pengurus Yayasan untuk mengklarifikasinya. ${ }^{3}$

Di kantor KPA ini di samping melayani semua pembayaran santri baik daftar ulang maupun spp perbulannya, juga melayani Tabungan Santri. Tangungan ini bisa di ambil santri tiap hari sesuai rekomendasi dari wali santri, misalnya wali santri menganjurkan anaknya jajan 10.000; perhari maka petugas tabungan ya mengeluarkannya tiap hari 10.000; kecuali untuk beli kebutuhan belajarnya atau yang lain bisa lebih dari 10.000; sesuai dengan kira-kira barang yang umum dibeli oleh santri.

Urusan gaji guru dan karyawan semua dihandel sama KPA. Perlu diketahui bahwa gaji guru dan karyawan harus melalui Bank BNIS, sehingga tiap guru dan karyawan harus punya rekening BNIS dan setiap awal bulan tiap lembaga harus menyetor rekapan absen guru dan karyawan, sehingga KPA tinggal merekap nominalnya saja, kemudian disetorkan ke bank BNIS dan pihak Bank mengautodebetnya ke rekening Yayasan Al Mahrusiyah.

Semua administrasi keuangan baik untuk lembaga Madrasah Aliyah, Madrasah Tsanawiyah, Sekolah Dasar, Pondok Putra atau Putri, Madrasah Diniyah Putra atau Putri dijadikan satu di kantor KPA(kantor pusat administrasi), sehingga para wali murid tidak usah repot dalam pembayaran spp atau syahriyahnya, mereka cukup datang di kantor pusat administrasi sudah bisa membayar semuanya.

Demi keamanan dan keefektifan keuangan di Yayasan Al Mahrusiyah, Yayasan bekerjasama dengan dua Bank yaitu Bank

3 Peraturan Transfer uang di Yayasan Al Mahrusiyah Lirboyo Kediri.
BNI Syari'ah dan Bank Jatim. Bank BNIS dengan nomor rekening 0777778000 atas nama Yayasan Al Mahrusiyah, Bank Jatim dengan nomor rekening 0772300000 juga atas nama Yayasan Al Mahrusiyah. Kerja sama tersebut meliputi pembayaran semua santri dengan cara semua santri harus punya rekening Bank yang kebetulan Bank BNIS yang ditunjuk Yayasan Sebagai Mitra utamanya, sedangkan Bank Jatim sebagai wadah pentrasferan wali santri saja.

Setiap kiriman uang dari wali santri bisa dilihat langsung di komputer bagian Brankas baik yang transfer ke BNIS atau di Bank Jatim dan langsung bisa direalisasikan oleh petugas pentransferan baik yang dialokasikan ke pembayaran atau pun yang dialokasiakan ke tabungan. Hal ini berlangsung tiap hari kecuali hari minggu dan hari-hari besar islam. Para wali santri bisa tanya langsung via telpon atau sms $\mathrm{k}$ KPA perihal pentransferan atau pembayaran dan tabungan.

Untuk biaya operasional semua lembaga, biaya operasional pembangunan sarana dan prasarana juga jadi satu di kantor pusat administrasi dengan cara membuat proposal. Semua proposal yang masuk di seleksi langsung oleh pihak bagian proposal yang di acc oleh pihak Yayasan, tentunya mempertimbangkan semua uang yang masuk dan sepuluh persennya harus masuk Yayasan. Contohnya proposal dengan jumlah total 50.000; untuk atk atau alat tulis kantor, maka tidak boleh dicairkan sesuai permohonan, harus dilihat uang masuk dari setiap siswa dalam aitem atk berapa, misalnya defisit setelah diambil 50.000;, maka harus dicairkan 25.000; dan seterusnya. ${ }^{4}$

\section{B. Mutu Pendidikan di Yayasan Al Mahrusiyah Lirboyo Kediri}

Kurang lebih pada tahun 1986 lembaga pendidikan yang ada di Yayasan Tribakti Lirboyo Kediri meliputi Perguruan tinggi Institut Agama Islam Tribakti, Madrasah Aliyah Tribakti, Madrasah Tsanawiyah Tribakti dan TK Tribakti Kediri. Semua lembaga Pendidikan

4 Data bagian Brankas yang juga bertugas mencairkan Proposal setelah mendapat rekomendasi dari Bendahara Yayasan. 
tersebut dalam satu lokasi yaitu sebelah selatannya Rumah Sakit Daerah Gambiran.

Perguruan Tingginya direktori oleh Beliau KH. Imam Yahya Mahrus Putra dari Pendiri Yayasan Tribakti KH. Mahrus Ali. Sedangkan Madrasah Aliyahnya dikepalai oleh Drs. H. Moh Masyhur atau terkenal dengan $\mathrm{H}$. Kuncoro Almarhum, beliau termasuk famili penulis yaitu pakdenya Istri penulis, menjabat beberapa periode. Tapi karena beberapa hal akhirnya beliau di nonaktifkan dari jabatanya tepatnya kurang lebih tahun 2001. Kemudian diganti oleh seseorang dari utusan kemenag kediri berlangsung kurang lebih 3 tahun diganti oleh Bapak Taufiq Hidayat, S. Ag. ${ }^{5}$

Pada waktu dikepalai oleh utusan dari kemenag ini Madarasah Aliyah mulai berangsur-angsur pindah lokasi ke dekat atau belakang Pondok HM Putra pada waktu itu, tapi sebelumnya sudah ada yang pindah ke lokasi yang sama yaitu Madrasah Tsanawiyah yang pada waktu itu dikepalai oleh bapak Nurhadi Zuhdin, BA Almarhum. Penulis sebagai pelaku sejarah tepatnya penulis sebagai Offis Boy pada waktu itu.

Sedangkan TK dan Perguruan Tingginya sampai sekarang masih berada di tempat semula yaitu di Tribakti Timur dekat Gambiran. Dan mulai pindah itu sekaligus mulai juga Rintisan Yayasan Al Mahrusiyah yang masih punya 2 lembaga pendidikan yaitu Madrasah Aliyah Al Mahrusiyah dan Lembaga Pendidikan Tsanawiyah Al Mahrusiyah sekaligus Pondok Pesantren HM Al Mahrusiyah yang dulunya Pondok HM Putra dan Madrasah Diniyah Al Mahrusiyah.

Sarana dan Prasarana dari Yayasan ini masih sederhana sekali. Untuk gedung Madrasah Formalnya saja masih pinjam gedung Al Barokah milik Pondok Pesantren Lirboyo Induk, apalagi Kantornya masih menggunakan bekas gudang tempat penyimpanan peralatan bangunan, sangat prihatin sekali pada waktu itu.

5 Sejarah awal berdirinya Yayasan Al Mahrusiyah Lirboyo Kediri.

\section{Mutu pendidikan Setelah Adanya Sentralisasi atau Kantor Pusat Administrasi Yayasan Al Mahrusiyah Lirboyo Kediri.}

Seiring berjalannya waktu dimana santri semakin lama semakin banyak,maka sarana dan prasarananya membutuhkan perbaikan dari segi kualitas dan kuantitasnya mulai dari Madrasah Tsanawiyahnya maupun Madrasah Aliyahnya. Tenaga pengajarnya yang dulu belum sarjana saja bisa mengajar seperti penulis sendiri baru tamat Madrasah Aliyah Hidayatul Mubtadiin saja sudah disuruh ngajar, sekarang paling tidak harus Sarjana baru bisa mengajar. Tenaga ketatausahaannya untuk waka harus sudah mengajar dan sarjana, tapi untuk kepala TU dan TUnya masih dari kalangan anak dalem dan belum sarjana. ${ }^{6}$

Sekarang tahun 2015 semuanya sudah berubah dengan perubahan yang signifikan. Dari kualitas siswanya, tenaga pengajarnya maupun tenaga yang mengurusi administrasinya, hampir semuanya tidak ada yang tidak sarjana. Kualitas siswa yang tiap tahunnya bisa diterima di perguruan tinggi negeri umum apalagi perguruan tinggi Islam. Sekarang seiring bertambahnya siswa bertambah pula lembaganya yaitu Lembaga Pendidikan Sekolah Menengah Kejuruan yang ada di Ngampel dan Lembaga Pendidikan Sekolah Dasar yang ada di Muning.

Laboratorium bahasa, laboratorium komputer, laboratorium IPA, laboratorium untuk bengkel komputer smk ngampel, laboratorium peternakan dan pertanian semuanya sangat menunjang sekali terhadap mutu atau kualitas belajar mengajar di Yayasan Al Mahrusiyah Lirboyo Kediri. Itu semua berkat dari sentralisasi administrasi Yayasan Al Mahrusiyah yang membawa persatuan dan kesatuan misi dan visi Yayasan yang memudahkan kontroling administrasi oleh Yayasan sehingga mempercepat terwujudnya cita-cita luhur pendiri Yayasan Al Mahrusiyah Lirboyo Kediri.

Di antara wujud kemajuan yang ada di Yayasan Al Mahrusiyah adalah AD (anggaran dasar) dan ART (anggaran rumah tangga)

6 Dari hasil wawancara dengan salah seorang khodimin Yayasan Al Mahrusiyah Lirboyo Kediri. 
Yayasan Al Mahrusiyah. Di mana sebelum ada KPA belum punya AD ART Yayasan, ini adalah kemajuan awal dari Yayasan Al Mahrusiyah Lirboyo Kediri.

\section{KESIMPULAN}

\section{Manajemen Keuangan di Yayasan Al Mahrusiyah Lirboyo Kediri}

Manajemen keuangan yang ada di Yayasan Al Mahrusiyah menganut paham sentralisasi manajemen terutama masalah keuangan. Sedangkan masalah yang lainnya masih belum keseluruhannya dapat di sentralisasi di Kantor Pusat Administrasi (KPA). Di antara masalah yang sudah disentralisasi selain keuangan adalah ketenagakerjaan yang ada, baik masalah pengrekrutan tenaga kerja maupun masalah pemutasian keluar tenega kerja yang tidak mentaati peraturan Yayasan.

Administrasi keuangan mulai dari pemasukan keuangan yang dihasilkan dari wali santri atau siswa dari hasil PSB atau dari BOS baik BOS madin, BOS Mts, BOS MA atau dari instansi Pemerintah maupun swasta semua masuk ke Kantor Administrasi Pusat (KPA). Administrasi keuangan pengeluaran untuk operasional atau pembelanjaan barang atau pengadaan sarana dan prasarana semuanya juga di Kantor Pusat Administrasi (KPA) Al Mahrusiyah Lirboyo Kediri.

\section{Mutu Pendidikan Yayasan Al Mahrusiyah Lirboyo Kediri}

Dari paparan data di BAB IV dan Analisis data di BAB $\mathrm{V}$ penulis menyimpulkan bahwa sentralisasi manajemen khususnya keuangan di Yayasan Al Mahrusiyah Lirboyo Kediri memberikan dampak yang signifikan dalam meningkatkan mutu atau kualitas Pendidikan di lembaga-lembaga pendidikan di bawah naungan Yayasan Al Mahrusiyah Lirboyo Kediri.

Hal tersebut berdasarkan fakta yang ada sampai hari ini, di samping pernyataan bapak Mahmudi Yunif, S. Si, yang penulis wawancarai pada selah-selah aktifitasnya sebagai direktur Kantor Pusat Administrasi
(KPA), beliau mengatakan bahwa berkat sentralisasi administrasi keuangan ini banyak kemajuan baik dibidang keuangan dengan ditandai kerjasamanya BNIS dengan Yayasan dimana setiap santri dan bapak ibu guru karyawan harus punya rekening BNIS, maupun bidang pendidikan yang dibuktikan dengan suksesnya ujian nasional dengan tingkat kelulusan yang maksimal.

Kemajuan yang terasa di bidang pendidikan dengan adanya sarana laboratorium bahasa, laboratorium IPA, laboratorium komputer dan Bengkel Komputer untuk sekolah menengah kejuruan (SMK), sarana dan prasarana ruang baik kelas maupun kantor sudah di lengkapi dengan CCTV sehingga memudahkan pengontrolan proses belajar mengajar bagi Yayasan itu sendiri. Di Kantor Pusat Administrasi (KPA) suasananya sudah sejuk dan nyaman karena ruangannya berAC dan berlantai dua, sehingga sudah tidak sempit lagi dan tidak harus antri lama.

Kemajuan-kemajuan di bidang pendidikan yang sifatnya non fisik di antarannya tingkat kelulusan di tahun 2015 untuk madrasah Aliyah, Tsanawiyah dan sekolah Kejuruan, 100\% semuanya lulus. Selain itu untuk Pondok Pesantren Al Mahrusiyah tingkat alumninya sudah banyak yang di terima di perguruan tinggi Yaman Al Afqof atau di Mesir.

\section{DAFTAR PUSTAKA}

Asmani, Jamal Ma'mur.(2012)Tips Aplikasi Manajemen Sekolah. DIVA Press, Jogjakarta.

Ahmad, Dzaujak.(1996)Petunjuk Peningkatan Mutu Pendidikan di Sekolah Dasar. Depdikbud, Jakarta.

Ahmadi, Rulam.(2005)Memahami Metodologi Penelitian Kualitatif. Universitas Negeri Malang Press, Malang.

Arikunto, Suharsimi.(2003)Manajemen Penelitian. Rineka Cipta, Jakarta.

.(2006) Prosedur Penelitian Suatu Pendekatan Praktik. Rineka Cipta,Jakarta. 
Barnawi \& M. Arifin.(2012)Manajemen Sarana \& Prasarana Sekolah. Ar-Ruzz Media, Jogjakarta.

B. Milles, Matthew dan Huberman.(1992) Analisis Data Kualitatif: Buku Sumber tentang Metode-Metode Baru. Tjetjep Rohendi Rohidi (terj.), UI Press, Jakarta.

Bungin, Burhan.(2005)Analisis Data Penelitian Kualitatif. PT. Raja Grafindo Persada, Jakarta.

Danim, Sudarwan.(2007)Visi Baru Manajemen Sekolah. Bumi Aksara, Jakarta. . (2008)Visi Baru Manajemen Sekolah; Dari Unit Birokrasi ke Lembaga Akademi.Bumi Aksara, Jakarta.

Diknas.(2002)Pendekatan Kontekstual (Contekstual Teaching Learning/CTL). Dikdasmen, Jakarta.

Engkoswara. (2001)Paradigma Manajemen Pendidikan Menyongsong Otonomi Daerah. Yayasan Amal Keluarga, Bandung.

Fattah, Nanang.(2009)Landasan Manajemen Pendidikan. PT. Remaja Rosdakarya, Bandung.

Fattah, Nanang \& Abu Bakar.(2001) Pengelolaan Keuangan Pendidikan, Pengantar Pengelolaan Pendidikan. Tim Dosen Jurusan Administrasi Pendidikan UPI, Bandung.

Fauzi, Imron.(2012)Manajemen Pendidikan ala Rasulullah. Ar-Ruzz Media, Jogjakarta.

Hadi, Sutrisno.(2000)Metodologi Research II. Andi Ofset, Yogyakarta.

Hamalik, Oemar.(1990) Evaluasi Kurikulum. Remaja Rosda Karya, Bandung.

Handoko, T. Hani Handoko.(2011)Manajemen Edisi 2. BPFE-UGM, Yogyakarta.

Harsono.(2007) Pengelolaan Pembiayaan Pendidikan. Tesis, STAIN Surakata.

Hartanti, A.L.(2011) Manajemen Pendidikan. LaksBang PRESSindo, Yogyakarta.
Hikmat.(2009) Manajemen Pendidikan. CV. Pustaka Setia, Bandung.

Ichsani.(2008) Transparansi Manajemen Keuangan,Studi di Pondok Pesantren Salaf dan Modern Masyithoh di Desa Bolo, Wonosegoro, Boyolali. Tesis, STAIN Surakarta.

Moleong, Lexy.(2000)Metodologi Penelitian Kualitatif.Remaja Rosdakarya, Bandung.

Mulyasa, E.(2007)Manajemen Berbasis Sekolah. Bandung: PT. Remaja Rosdakarya,

Mulyono.(2010) Manajemen Administrasi \& Organisasi Pendidikan.ARJogjakarta: Ruzz Media

Muliono, Anton.(1993)Kamus Besar Bahasa Indonesia. Balai Pustaka, Jakarta.

Nasution, S.(1996)Metodologi Penelitian Naturalistik Kualitatif. Tarsito, Bandung.

Patttilima, Hamid. (2005)Metode Penelitian Kualitatif. Alfabeta, Bandung.

Poerwadarminta, W.J.S.(1996)Kamus Lengkap Inggris Indonesia. Balai Pustaka, Jakarta.

Prastowo, Andi.(2012)Metode Penelitian Kualitatif dalam Perspektif Rancangan Penelitian. Ar-ruzz Media, Jogjakarta.

Riyatno, Yatim. (2001)Metodologi Penelitian Pendidikan. Penerbit SIC, Surabaya.

Riyatno, Yatim.(2008) Metodologi Penelitian Pendidikan Kualitatif dan Kuantitatif. Unesa Press, Surabaya.

S. Arcaro, Jerome.(2005)Pendidikan Berbasis Mutu, Prinsip-Prinsip dan Tata Langkah Penerapan. Pustaka Pelajar, Yogyakarta.

S. Sukmadinata, Nana.(2009)Metode Penelitian Pendidikan.Rosdakarya, Bandung.

Safi'i, Asyrof.(2005)Metodologi Penelitian Pendidikan; Aplikasi Praktis Penelitian Pembuatan Usulan (Proposal) dan Penyusunan Laporan Penelitian. eLKAF, Surabaya. 
Sagala, Syaiful.(2004)Manajemen Berbasis Sekolah dan Masyarakat. PT. Nimas Multima, Jakarta.

(2009) Memahami Organisasi Pendidikan. Alfabeta, Bandung.

Sallis, Edward.(2011)Manajemen Mutu Terpadu Pendidikan. IRCiSoD, Jogjakarta.

Saroni, Mohammad.(2012) Orang Miskin Harus Sekolah. Ar-Ruzz Media, Jogjakarta.

Satori, Djam'an dan Aan Komariyah. (2010) Metodologi Penelitian Kualitatif. Alfabeta, Bandung.

Sidi, Indra Djati.(2003) Menuju Masyarakat Belajar. Logos, Jakarta.

Sugiono.(2001) Metode Penelitian Kuantitatif, Kualitatif, dan $R \& D$. Alfabeta, Bandung.

Suhardan, Dadang. (2001)Organisasi dan Manajemen Pendidikan Nasional dalam Pengantar Pengelolaan Pendidikan. Tim Dosen Jurusan Administrasi Pendidikan UPI, Bandung.
Sulistyorini. (2006) Manajemen Pendidikan Islam. Elkaf, Surabaya.

Suprayogo dan Thobroni. (2003)Metodologi, Metodologi Penelitian Sosial Agama. Remaja Rosdakarya, Bandung.

Suratno, Sri.(2005) Manajemen Pembiayaan Pendidikan, Studi Kasus di SD Islam Unggulan Bazra Sragen. Tesis, STAIN Surakarta.

Tanzeh, Ahmad. (2009)Pengantar Metode Penelitian. Teras, Yogyakarta.

Tim Penyusun.(1999) Kamus Besar Bahasa Indonesia. Balai Pustaka, Jakarta.

Tjiptono, Fandi dan Anastasia Diana. (2009) Total Quality Management. Andi Offset, Yogyakarta.

Umiarso \& Imam Gojali. (2011)Manajemen Mutu Sekolah di Era Otonomi Pendidikan. IRCiSod, Jogjakarta.

DPR RI. (2006)Undang-undang Republik Indonesia Nomor 20 Tahun 2003 tentang Sistem Pendidikan Nasional. Bandung: Fokus Media, 